\title{
The applicability of the concept of treatment adherence in the context of the Brazilian mental health system*
}

\author{
Aplicabilidade do conceito de adesão ao tratamento no contexto da saúde mental brasileira \\ Aplicabilidad del concepto de adhesión al tratamiento en \\ el contexto de la salud mental brasileña
}

Patricia Elizabeth Sanz de Alvarez¹, Ernestina Rosendo², João Carlos Alchieri ${ }^{3}$

\footnotetext{
* This manuscript is part of the doctoral thesis in progress: "Adherence to treatment: epidemiologic profile, perceptions and expectations of users of the public mental health system in a municipality of the Brazilian Northeast", the first author (student at the USAL - Argentina and CAPES Brazil Full Doctoral Fellow) directed and codirected by the second and the third author respectively.

${ }^{1}$ CAPES-Brazil Doctoral Fellow in Psychology at the University of Salvador (USAL), Buenos Aires, Argentina.

${ }^{2}$ Doctorate in Mental Health from the UBA University of Medicine. Professor, Department of Psychology Research, University of Salvador (USAL), Buenos Aires, Argentina.

${ }^{3}$ Doctorate in Psychology. Professor in the Graduate Department of Psychology, Federal University of Rio Grande do Norte (UFRN), Natal, Brazil
}

\section{ABSTRACT}

Objective: to present reflections on the type of research conducted on a treatment adherence among users of Public Mental Health System in Brazil and discuss the applicability of the concept of adherence to treatment in this context. Method: literature review in SciELO, LILACS, Cochrane Library and PubMed / MEDLINE using the Health Sciences Descriptors (DeCS) treatment, adhesion and "mental health" and the specific vocabulary of the Medical Subject Headings (MeSH) "patient compliance/psychologist" y "mental health". They were included for review the complete texts and theses published between 2007-2012 in Portuguese, English and Spanish. Results: 127 articles were recovered, 32 specifically related to mental health. Eight were excluded for duplicates and after reading the remaining 24 articles were selected for this study 10 conducted in the field of Mental Health in Brazil. No investigations have been identified with focus on adherence to psychosocial treatment offered in public mental health. Conclusion: the studies analyzed not considered the context and complexity of the offered treatment, disregard of the mental health legislation and reinforce the asylum model of assistance.

\section{DESCRIPTORS}

Adherence; treatment; mental health. 


\section{INTRODUCTION}

Mental disorders affect people regardless of social class and economic status, and because of their high prevalence, they represent a significant global public health challenge ${ }^{(1)}$. Scholars disagree on the impact of etiological factors and their tendency toward chronicity ${ }^{(2)}$, but regardless, mental disorders unequivocally have a negative impact on the quality of life and well-being of people suffering with mental illness and their families. In addition, untreated symptoms and comorbidities that can occur as other illnesses - be they psychiatric or not lead to an increased investment in the health system.

Represented in numbers, it is estimated that over 10 million Brazilians require specialized mental health care ${ }^{(1)}$. Given the recurrent nature of mental disorders and because it is essential that assistance be given during both phases of crisis and of maintenance and prevention, the needed care can result in prolonged treatments ${ }^{(3)}$.

Some authors assert that due to the need for continuous treatment, patients suffering from chronic conditions often have difficulties completing their treatment plans. At times, treatments can be painful, which is also true for cases of mental illness ${ }^{(4)}$. Moreover, it would be possible to reduce the risk of chronicity through early disease diagnosis and through promoting treatment adherence ${ }^{(5)}$. Given this situation, it can be said that the maintenance of treatment, rather than access and availability, is most crucial.

In the case of people suffering from mental illness, including those who are affected by the harmful effects of crack, alcohol, and other drugs, treatment is offered in the context of the Brazilian Unified Health System (UHS) within the framework of the Psychiatric Reform and Mental Health Policy ${ }^{(6)}$, which is characterized by its multi-level and multi-mechanism network.

Psychosocial Care Networks (PCNs) consist of primary care, strategic psychosocial care, urgent and emergency care, short-term home care, in-patient care, and a deinstitutionalization strategy. Specifically, Psychosocial Care Centers (PCCs) are located at the Strategic Psychosocial Care level - also known as Specialized Psychosocial Care. These mechanisms, in their various forms for Mental Illness (PCC-MI) and Alcohol and Drugs (PCC-AD), may or may not provide beds for the overnight placement of patients in crisis.

Originally codified in 1992 by ordinance 224 of the Ministry of Health, which defined them as local/regional health centers, the PCCs have an assigned population according to their location. They provide intermediate care, between outpatient and hospitalization, in 1 or 24 -hour shifts by a team of professionals. Since 2002, the PCCs have been regulated by ordinance $336^{(7)}$, which includes them in the UHS framework in recognition of the complexity and breadth of the activities and services that they provide, referring as much to the territory where they are located as to the goal of replacing the centralized, hospital-based model of mental health care.

In that sense, the PCCs offer treatment to UHS users that is delivered by an interdisciplinary team composed of psychiatrists, psychologists, nurses, social workers, art educators, physical educators, and nursing technicians, among others. Psychosocial treatment is intended to encourage the integration of users, promoting their reintegration into the family and social fabric. In addition to providing medical and psychological care, it also offers support to users in their efforts to find autonomy ${ }^{(8)}$.

The main feature of the Psychosocial Model is based on an approach that seeks the biopsychosocial welfare of its users. Note that the use of the word "user" as opposed to "patient" relates to the view that health care is a human and social right, governed by citizenship. The user concept includes not only the biological but also the psychosocial perspective. It encompasses the individual in all of his or her dimensions, regardless of the presence or absence of disease, and it refers to the person being treated. In this sense, users are availing themselves of their rights as citizens to access health services ${ }^{(9)}$.

\section{Objective}

Because most mental health experts who research the phenomenon of treatment adherence refer to it exclusively as medical treatment; and in light of the scope and complexity of the comprehensive treatment offered in the PCCs, which was designed to be interdisciplinary to overcome the limits imposed by each academic background and to enable the rights of users, including the creation of an individualized therapeutic regimen, the aim of this article is to discuss the applicability of the concept of treatment adherence in said context. In parallel, we reflect on the types of studies that are conducted to measure treatment adherence among users of the Public Mental Health System in Brazil.

\section{METHODS}

Our methodological strategy was to employ a systematic literature review of the SciELO, LILACS, Library Cochrane, and PubMed/MEDLINE databases. Keywords were selected from Health Sciences Descriptors (DeCS) and the specific vocabulary of the Medical Subject Headings (MeSH). The selected DeCS keywords were "adherence", "treatment", and "mental health"; in MeSH, they were "patient compliance/psychologist" and "mental health". As inclusion criteria, we focused on full text articles and published theses from 2007 to 2012 in Portuguese, English, and Spanish. The material was classified in identification files using Excel for Windows software, and a summary of the main concepts under investigation was included. To provide greater reach and a more theoretical basis for discussion, some secondary sources (works referenced by the selected authors in the initial search) were also included.

The points that will be primarily analyzed in this paper are the following: the concept of adhesion, the academic training area of the researchers, the type of research design and instruments used, the objectives, and the context in which the study was conducted. Notably, these data are part of ongoing qualitative doctoral research being conducted by the first author under the direction of the second author 
and co-direction of the third author. The research, which follows the rules of Resolution 466/2012, was authorized by the Municipal Secretary of Health and approved by the Research Ethics Committee of the Federal University of Rio Grande do Norte, under dictum 510825/2014.

\section{RESULTS}

In the initial search, 127 articles were retrieved, and after reading the title and abstract, 95 that related to the medical specialties of pediatrics, cardiology, oncology, hematology, immunology and forensic psychiatry were excluded. Of the 32 articles specifically related to mental health, 8 were excluded as duplicates because they were recorded in more than 1 database. The remaining 24 items were then read, and 10 of them - those corresponding to research on the field of Mental Health in Brazil - were selected for this study. Of this group, 2 were published in 2008, 4 in 2009, 2 in 2011, and 1 in 2012, showing that there has been sustained research interest on the subject.

\section{DISCUSSION}

A discussion of the concept of treatment adherence is necessary because the literature on this topic is inconclusive. Thus, authors who show a preference for either the use of the word adherence or adhesion were identified. A wide variety of applications and adaptations that justify questioning the scope, limitations, or applicability of both concepts in the field of Brazilian mental health were found.

The first studies found in the literature related to treatment adherence date back to 1967 , the year in which research was published on compliance with treatments to control hypertension ${ }^{(10)}$. Gradually, interest in this issue increased in the medical community, and studies were extended to other diseases.

In these early studies, researchers used the word compliance, defined by some as "participatory and active obedience by the patient to the medical prescription". It was understood that the prescription referred not only to medicines but also to any other actions or measures that were recommended by the doctor or any other health professional ${ }^{(11)}$. Other authors suggest that the use of the word compliance - obedience - assumes a passive role on the part of the patient whereas adherence - fulfillment/adherence would be more appropriate because it implies the freedom of choice that people have to accept or reject certain treatment recommendations ${ }^{(12)}$.

It is noteworthy that in the 2004 Spanish publication of a book by the $\mathrm{WHO}^{(13)}$, the following translated title was used: "Adherence to long-term treatments: evidence for action". We believe that the use of the word adherence by the largest institution of the United Nations governing health activities was crucial to beginning the trend by many authors of adopting the term adherence.

However, among Spanish-speaking researchers, we identified Spanish authors ${ }^{(14)}$ who disagreed with the use of the word adherence because they understood adherence to be the quality of being adherent, whereas to signify the action and the effect of adhering to something - in the sense of agreeing with it and supporting it - it would be more appropriate to use the substantive adhesion. They understand that by itself, the word adherence does not denote the involvement and participation of the patient in the treatment, which goes beyond mere compliance or fulfillment, and to be more precise, they defend the use of the expression "adhesion to treatment".

Evidently, difficulties with terminology hinder understanding the patient's position as active or passive in his or her treatment ${ }^{(15)}$. The findings in the literature state that over the course of history, what determines adhesion has fluctuated between the authority of the physician and patient autonomy ${ }^{(16)}$. For example, in the first half of the twentieth century, the patient was viewed as a passive participant in the treatment relationship. However, after World War II when the civil rights movement emerged, patients were given increased autonomy over treatment decisions ${ }^{(17)}$.

\section{Perspective approach to treatment adhesion}

From the analysis of the studies published in Portuguese, it was verified that the terms aderência and adesão - corresponding to adherence and adhesion, respectively - are used interchangeably. Some of researchers rely on the WHO concept noted above $\mathrm{e}^{(18-19)}$. Others explain their choice of the term "adhesion" to convey the more active participation of patients ${ }^{(20)}$ or use derivative terms, retaining the first word, adhesion, and using a word synonymous with treatment to increase the degree of accuracy. Such is the case with "therapeutic adhesion" (21), the "adhesion to therapeutic plans"(22), and the "adhesion to the therapeutic process of mental health services"(23).

It should be noted that these last 2 articles do not address adhesion in terms of comprehensive, psychosocial treatment at the regional and community level, despite the fact that the studies were within the context of care delivered through PCCs in Brazil and despite the focus on the social reintegration of patients, which is offered in the field of public mental health in Brazil. However, their objectives utilized terms related to the mental health field. What was observed is the medical-pharmacological dominance introduced in the concept of a "therapeutic project", which is restricted exclusively to psychopharmacological prescriptions and minimizes the psychosocial treatment model defined by the public policy guidelines implemented in the Brazilian mental health field.

From the broader perspective of the $\operatorname{clinic}^{(24)}$ and within the framework of the mental health field post-psychiatric reform, the therapeutic project becomes more important, as it represents a unique development that is appropriate to the needs and characteristics of each user. That is, medical attention should be personalized such that the treatment inside and/or outside the clinic - is planned according to the user's individual needs and with regard for his or her unique circumstances. The importance of the Singular Therapeutic Project (STP) relies on the premise that patients have the power to transform their relationship with their health and their illness and, in doing so, to realize that the 
choices of the user are theirs alone and that they will say if and when they want to agree with, negotiate, or reject the suggestions made by their health team ${ }^{(25)}$.

It should be emphasized that most of the analyzed studies quantify adhesion to psychopharmacological treatment, measuring the intake of prescription drugs or compliance with other procedures, such as observing schedules, dosages, and treatment durations ${ }^{(18-19,26-27)}$. In some cases, the measurement was based on the frequency with which the patient follows the recommendations of the consulting professional, returns to the health service for consultation, or adheres to prescribed medical treatments ${ }^{(21)}$.

Expanding the number of variables but with the same psychopharmacological focus, 1 of the studies included absences at consultations, the refusal of the user to accept hospitalization, reluctance to initiate psychosocial treatments, and prematurely dropping out of treatment ${ }^{(22)}$. Regarding the latter case and specifically because the study was conducted in a PCC, it is worth noting that the inclusion of reluctance to initiate psychosocial treatment as an analysis variable clearly identifies the author's perspective, that he or she perceives Psychopharmacological Treatment and Psychosocial Treatment separately, although the author did not include any discussion on the matter.

\section{Methodological deCisions: Research Design AND [SURVEY] INSTRUMENTS}

Regarding the research design, Brazilian researchers in the area of Nursing and Psychiatry ${ }^{(18-19,26-27)}$ show a preference for designs considered to be "robust" (28) and for the consistent application of related instruments, such as structured interviews, scales, and tests, to collect data that are then analyzed quantitatively. Only 2 of the studies reviewed ${ }^{(21,26)}$ involve mixed methodologies and utilize a quantitative analysis of the test results and qualitatively analyzed semi-structured interviews.

Next, 3 studies were identified with an epistemological basis exclusively supported by a qualitative paradigm. One was in the Nursing field ${ }^{(29)}$ and used participant observation and semi-structured interviews. The others, in the Psychology field ${ }^{(20.23)}$, showed an equal preference for semi-structured interviews.

\section{Study Context and Research Objectives}

Regarding the study context and most likely due to confidentiality concerns, the terms used by most researchers were diverse and generalized, which made identification difficult ${ }^{(20-21,26-27-30)}$. However, it was possible to determine that 3 of the studies were conducted in PCCs ${ }^{(22-23,29)}$ and 2 in Outpatient University Clinics ${ }^{(18-19)}$.

Regarding the objectives, there were 7 researchers who verified medication adherence, 5 of whom were in Nursing fields ${ }^{(18-19,21,26,30)}$ and 2 in Psychology ${ }^{(20.22)}$. However, 1 of the latter examined the effectiveness of interventions contributing to drug adherence ${ }^{(20)}$. It is important to highlight another study conducted by a researcher in the Nursing field $^{(29)}$. In this study, despite stating that the aim was to evaluate the influence of psychosocial interventions on the social lives of patients, the author warns against a dichotomous view of the offered treatments, and emphasis is placed on psychosocial interventions that function as a therapeutic resource intended to improve drug treatment adherence.

Another study in the field of Psychology investigated the barriers that develop among the patients, family members, and professionals ${ }^{(23)}$. The aim of the author was to show that the tension that exists within the institution between family members and professionals negatively impacts patient adherence and medication treatment.

\section{CONCLUSION}

It is true that among the studies reviewed, there was a tendency to rely on the concept of treatment adherence described by the WHO and defined as the degree of agreement between the recommendations of the health team and the behavior of the patient. It is also clear that there were other researchers identified who offered additional contributions, expanding the definition from simply indicating adherence to a specific type of treatment to considering the treatment as a process.

In this sense and from our perspective, we agree with the acknowledgements of users' rights and with the empowerment of patients to have increased autonomy over decisions related to their treatment. Moreover, we agree with Garcia-Garcia (2010) and understand that the word adherence does not refer to the involvement and participation of the patient in the treatment. We advocate the use of the term "treatment adhesion" adopted in this article because it goes beyond mere compliance and fulfillment.

Moreover, regardless of the field of academic training of the authors we analyzed, unanimity was observed in restricting the treatment to the psychopharmacological plan, limiting their research to measuring the intake of prescription drugs and applying their own concepts and methods of analysis, from their quantitative and positivist paradigm, to the mental health field.

We believe that the primary role in the conceptualization and usage of the term "treatment adhesion" surpasses the patient's active or passive role in treatment and is related to the theoretical and methodological opinion of the investigator, requiring further reflection on the peculiarities of the research context, which often defines a type of treatment that is more complex than the traditional medical model.

Unquestionably, the studies reviewed suffer from problematizations that allow them to measure the significance of evaluating adhesion to medical-pharmacological treatment while disregarding the complexity of the psychosocial treatment provided to users of the public mental health network. In other words, by not considering the specificities of the mental health field and the characteristics of the treatments offered in the psychosocial care model, isolated academics end up reinforcing previous narrow-minded perspectives. It should be noted that changes in the perspective of care arise from the process of Psychiatric Reform within the framework of recovering the country's 
democratic life ${ }^{(6)}$, a model that was strengthened in 2001 when regulation 10.216 , which addresses the protection and rights of patients with mental disorders, was passed ${ }^{(31)}$.

Finally, on the subject of applicability, we understand that the definition of this term, in accordance with its etymology, is the quality of its applicability. If we define applicable as being anything that can or should be applied and/ or implement a specific understanding to achieve a certain effect, then we understand that it is necessary to build a concept of adhesion to treatment that applies to the context of Brazilian mental health.
Therefore, we propose that when referring to "treatment adhesion in the mental health field", we refer to the complex and multiple phenomena as a function of the multiplicity of interventions and the complexity of the treatment itself. Regarding complexity, we specifically note that from this perspective, adhesion may fluctuate as a function of unique times and circumstances. In addition to referring to the myriad dimensions that compose treatment, we consider that the patient dimension, the family, the interdisciplinary team, and the direct or indirect impact of the institutional political context must all be addressed.

\section{RESUMO}

Objetivo: apresentar reflexões sobre o tipo de pesquisa que são realizados sobre a adesão ao tratamento entre os usuários do Sistema de Saúde Mental Pública no Brasil e discutir a aplicabilidade do conceito de adesão ao tratamento neste contexto. Método: revisão da literatura nas bases SciELO, LILACS, Cochrane Library e PubMed/MEDLINE utilizando os descritores de Ciências da Saúde (DeCS) tratamento, adesão e "saúde mental" e o vocabulário específico do Medical Subject Headings (MeSH) "patient compliant/psychologist" e "mental health". Foram inclusos para revisão os textos completos e as teses publicadas entre 2007-2012, em Português, Inglês e Espanhol. Resultados: 127 artigos foram recuperados, 32 especificamente relacionados com a saúde mental. Oito duplicados foram excluídos, dos 24 restantes foram selecionados para este estudo os 10 realizados no campo da Saúde Mental no Brasil. Não se identificaram pesquisas com foco na adesão ao tratamento de perspectiva psicossocial oferecido na saúde mental pública. Conclusão: as pesquisas analisadas desconsideram o contexto e a complexidade do tratamento oferecido, desconhecem a legislação de saúde mental em vigor e reforçam o modelo manicomial de assistência.

\section{DESCRITORES}

Adesão; tratamento; saúde mental.

\section{RESUMEN}

Objetivo: presentar reflexiones sobre el tipo de investigaciones realizadas en Brasil sobre la adhesión al tratamiento de los usuarios del Sistema Público de Salud Mental y discutir la aplicabilidad del concepto de adhesión al tratamiento en dicho contexto. Método: revisión bibliográfica en las bases SciELO, LILACS, Biblioteca Cochrane y PubMed/MEDLINE utilizando los descriptores de Ciencias de la Salud (DeCS) adhesión, tratamiento y "salud mental" y el vocabulario específico de Medical Subject Headings (MeSH) "patient compliance/psychologist" y "mental health". Se incluyeron los textos completos y las tesis publicadas entre 2007-2012, en portugués, inglés y español. Resultados: fueron recuperados 127 artículos, 32 específicamente de la salud mental. Se excluyeron los 8 duplicados y de los 24 restantes fueron seleccionados para el presente trabajo los 10 realizados en Brasil. No se identificaron enfoques sobre la adhesión al tratamiento de perspectiva psicosocial ofrecido en la red pública de salud mental. Conclusión: las investigaciones analizadas desconsideran el contexto y la complejidad del tratamiento ofrecido desconociendo la legislación en salud mental vigente y reforzando el modelo de atención asilar.

\section{DESCRIPTORES}

Adhesión; Tratamiento; Salud Mental.

\section{REFERENCES}

1. Mari JJ, Jorge MR, Kohn R. Epidemiologia dos transtornos psiquiátricos em adultos. In: Mello MF, Mello AA., Kohn R. "Epidemiologia da Saúde Mental no Brasil" (pp. 119-141). Porto Alegre: ArtMed, 2007.

2. Dalgalarrondo P. "Psicopatologia e semiologia dos transtornos mentais". Porto Alegre: Artmed Editora, 2000.

3. Lacaz FS. Adesão ao tratamento farmacológico na esquizofrenia. In: Shirakawa I. (Ed.), Esquizofrenia: adesão ao tratamento (pp. 19-45). São Paulo: Casa Leitura Médica, 2007.

4. Lenroot R, Bustillo JR., Lauriello J, Keith S. Integration of Care: Integrated treatment of schizophrenia. Psychiatr Serv. [Internet] 2003 Nov [citado 2015 Nov 17] 54(11), 1499-1507 Available from: http://ps.psychiatryonline.org/doi/pdf/10.1176/appi.ps.54.11.1499

5. Shirakawa I. (Ed.). Esquizofrenia: adesão ao tratamento. São Paulo: Casa Leitura Médica, 2007.

6. Brasil, Ministério da Saúde. Secretaria de Atenção à Saúde. DAPE. Coordenação Geral de Saúde Mental. Reforma Psiquiátrica e Política de Saúde Mental no Brasil. Documento apresentado na Conferência Regional de Reforma dos Serviços de Saúde Mental: 15 Anos depois de Caracas. OPAS. Brasília, 2005.

7. Brasil. Ministério da Saúde. Portaria GM n 336, de 19 de fevereiro de 2002. Define e estabelece diretrizes para o funcionamento dos Centros de Atenção Psicossocial. Diário Oficial da União 2002. [citado 2015 Nov 17] Disponível em: http://www.saude.mg.gov.br/ index.php?option=com_gmg\&controller=document\&id=838

8. Brasil, Ministério da Saúde. Saúde Mental no SUS: os Centros de Atenção Psicossocial. [Internet] 2004 [citado 2015 Nov 17] pp.01-86. Disponível em: http://www.ccs.saude.gov.br/saude_mental/pdf/sm_sus.pdf 
9. Alvarez PES, Rosendo E, Alchieri JC. Features of the patients attended in public mental health services of the Natal city/RN/Brazil: sociodemographic and epidemiological profile. Anu. Investig. [on line] 2015 [citado 2015 Nov 17] vol.22, pp 333-342. Available from: http://www.psi.uba.ar/docentes_graduados.php?var=investigaciones/revistas/anuario/anuario.php

10. Haynes et al. Improvement of medication compliance in uncontrolled hypertension. Lancet. [Internet] 1976 [citado 2015 Nov 17] 1, pp. 1265-8. Available from: http://www.ncbi.nlm.nih.gov/pubmed/73694

11. Gusmão JL, Mion DJ. Adherence to treatment - concepts. Rev Bras Hipertens. [Internet] 2006 [citado 2015 Nov 17] vol.13(1), 23-25. Available from: http://departamentos.cardiol.br/dha/revista/13-1/06-adesao-ao-tratamento.pdf

12. Brawley L, Culos-Reed N. Studying adherence to therapeutic regimens: overview, theories, and recommendations. Control Clin Trials. [Internet] 2000 [citado 2015 Nov 17] 21:1, 56-63. Available from: http://www.sciencedirect.com/science/article/pii/S0197245600000738

13. Organización Mundial de la Salud. Adherencia a los tratamientos a largo plazo. Pruebas para la acción. [Internet]. 2004. Available from: http://www.paho.org/hq/index.php?option=com_docman\&task=doc_view\&gid=18722\&ltemid

14. Garcia-Garcia, A. El fármaco y la palabra: Adherencia o adhesión?. Actualidad en Farmacología y Terapéutica. [Internet] 2010 Jun [citado 2015 Nov 17] 8(2), 128-128. Available from: http://www.socesfar.com/attachments/article/95/aftvol8.pdf

15. Lingam R, Scott J. Treatment non-adherence in affective disorders. Acta Psychiatr Scand. [Internet] 2002 Mar [citado 2015 Nov 17] 105(3), 164172. Available from: http://onlinelibrary.wiley.com/doi/10.1034/j.1600-0447.2002.1r084.x/full

16. Attux C. Adesão ao tratamento na esquizofrenia. In: Shirakawa I. Editor. Esquizofrenia: Adesão ao tratamento. São Paulo: Casa Leitura Médica. 2007.

17. Blackwell B. Treatment compliance. In: Kaplan B, Sadock V, editors. Comprehensive textbook of psychiatry, 7 ed. Philadelphia: Lippincott Willians \& Willians. 2000.

18. Cardoso L, Miasso Al, Galera SAF, Maia BM, Esteves RB. Adherence level and knowledge about psychopharmacological treatment among patients discharged from psychiatric internment. Rev. Latino-Am. Enfermagem [Internet]. 2011 Out [citado 2015 Nov 17]; 19( 5 ): 1146-1154. Available from: http://www.scielo.br/scielo.php?script=sci_arttext\&pid=S0104-11692011000500012\&lng=pt.

19. Cardoso L, Galera SAF. Mental patients and their compliance profile to psychopharmacological treatment. Rev. esc. enferm. USP [Internet]. 2009 Mar [citado 2015 Nov 17]; 43(1): 161-167. Available from: http://www.scielo.br/scielo.php?script=sci_arttext\&pid=S0080$-62342009000100021 \& \operatorname{lng}=$ pt.

20. Cunha MF, Gandini RC. Compliance and non compliance to the pharmacological treatment for depression. Psicologia: Teoria e Pesquisa [Internet]. 2009 [citado 2015 Nov 17]; 25(3), 409-418. Available from: http://www.scielo.br/scielo.php?script=sci_arttext\&pid=S0102$-37722009000300015 \& \operatorname{lng}=$ pt\&tlng=pt.

21. Miasso Al, Monteschi M, Giacchero KG. Bipolar affective disorder: medication adherence and satisfaction with treatment and guidance by the health team in a mental health service. Rev. Latino-Am. Enfermagem [Internet]. 2009 Ago [citado 2015 Nov 17] ; 17( 4 ): 548556. Available from: http://www.scielo.br/scielo.php?script=sci_arttext\&pid=S0104-11692009000400018\&lng=pt.

22. Marini M. Predictors of adherence to therapeutic plans in an alcohol and other drugs rehabilitation center. [Dissertação mestrado] Porto Alegre: Universidade Federal do Rio Grande do Sul. Escola de Enfermagem; 2011. 88p. [citado 2015 Nov 17]. Available from: http:// hdl.handle.net/10183/36963

23. Pimenta ES Romagnoli RC. The relationship with the families in the treatment for mentally troubled patients at the psychosocial attention Center. Pesqui. prát. Psicossociais, [citado 2015 Nov 17] 3(1), 75-84, 2008. Available from: http://www.ufsj.edu.br/portal2-repositorio/ File/revistalapip/volume3_n1/pdf/Pimenta_Romagnoli.pdf

24. Campos GWS. A clínica do sujeito: por uma clínica reformulada e ampliada. In: Campos, GWS. Saúde Paidéia (pp.51-57). São Paulo: Hucitec, 2003.

25. Brasil, Ministério de Saúde. Cartilha da PNH Clínica Ampliada, Equipe de Referência e Projeto Terapêutico Singular. 2. ${ }^{a}$ edição $1 .{ }^{a}$ reimpressão. Brasília/DF: Editora MS. [citado 2015 Nov 17] 2008. Disponível em: http://bvsms.saude.gov.br/bvs/publicacoes/clinica_ampliada_equipe_referencia_2ed_2008.pdf

26. Cruz LP, Miranda PM, Vedana KG, Miasso AI. Medication therapy: adherence, knowledge and difficulties of elderly people from bipolar disorder. Revista Latino-americana de Enfermagem, [citado 2015 Nov 17] 19(4), 944-952, 2011. Available from: http://www.scielo.br/pdf/rlae/v19n4/13.pdf

27. Ribeiro S, Alves MJM, Vieira EMM, Silva PM, Lamas CVD. Factors associated to treatment dropout in mental health. Jornal Brasileiro de Psiquiatria, [citado 2015 Nov 17] 57(1): 16-22, 2008. Avaliable from: http://www.scielo.br/scielo.php?script=sci_abstract\&pid=S0047$-20852008000100004 \& \operatorname{lng}=\mathrm{en} \& n r m=i s o \& t \operatorname{lng}=\mathrm{en}$

28. Sousa VD, Driessnack M, Mendes IAC. An overview of research designs relevant to nursing: Part 1: quantitative research designs. Rev. Latino-Am. Enfermagem, Ribeirão Preto, [citado 2015 Nov 17] v. 15, n. 3, June 2007. Avalilable from: http://www.scielo.br/scielo. php?script=sci_arttext\&pid=S0104-11692007000300022\&lng=en\&nrm=iso\&tlng=en

29. Moll MF, Saeki T. Social life of people with diagnosis of schizophrenia, attended at a psychosocial care Center. Revista latino-americana de enfermagem, [citado 2015 Nov 17] 17(6), 995-1000, 2009. Available from: http://www.scielo.br/pdf/rlae/v17n6/pt_11.pdf

30. Miasso AI, Carmo BP, Tirapelli CR. Bipolar affective disorder: pharmacotherapeutic profile and adherence to medication. Revista da Escola de Enfermagem da USP, [citado 2015 Nov 17] 46(3), 689-695, 2012. Available from: http://www.scielo.br/pdf/reeusp/v46n3/en_22.pdf

31. Brasil. Ministério da Saúde. Lei n. ${ }^{\circ}$ 10.216, de 06 de abril de 2001. Lex-Legislação em Saúde Mental 1990-2004, 5.ed. amp, Brasília; [citado 2015 Nov 17] 2004. Disponível em: http://bvsms.saude.gov.br/bvs/publicacoes/legislacao_saude_mental_1990_2004_5ed.pdf

\section{ACKNOWLEDGEMENTS}

To the CAPES Brazil (BEX 9702-13-0) - by granting the doctoral scholarship to the first author. 